DOI: 10.17707/AgricultForest.62.3.22

\author{
Milić ČUROVIĆ, Katarina PAVIĆEVIĆ, \\ Milena ĐOKIĆ, Dragana DROBNJAK ${ }^{1}$
}

\title{
ANALYSIS OF THE ENERGY POTENTIAL OF AGRICULTURAL BIOMASS RESIDUES IN MONTENEGRO
}

\begin{abstract}
SUMMARY
This paper gave an overview of the energy potential of organic remains from agricultural primary production and waste from livestock production in Montenegro. It has been estimated that approximately 9490 tons of dry mater of agricultural plant production residue is available. Intensive livestock farming results in production of 107.675 tonnes of waste.

The estimation of technical energy potential of crop residues amounts about $142.283 \mathrm{GJ}(39,56 \mathrm{GWh})$. The technical potential calculated on the basis of the availability and total animal fund results in total of $298.552 \mathrm{GJ}(82,93 \mathrm{GWh})$ of energy potential. Technical energy potential of agricultural waste is about $440.835 \mathrm{GJ}(122,49 \mathrm{GWh})$ per year. This potential is significantly lower than the theoretical potential.
\end{abstract}

Keywords: Biomass, technical energy potential, agricultural residues, Montenegro

\section{INTRODUCTION}

Agricultural land covers the $230.321,2$ ha which means $16,7 \%$ of the total land area in Montenegro. The major part of the agricultural land (216.583,4 ha) is characterized as permanent meadows and pastures (grassland), while the area dedicated to the cultivation of various crops (Utilised arable land) was 6.898,4 ha or just $0,5 \%$ of the total land in Montenegro in 2014. Montenegrin agriculture is characterized by traditional production, extensive methods of production and fragmented holdings with average size of 5 hectares. Total number of households is about 48.000 .

The estimation of the quantities of agricultural residues available for energy production depend on the degree of availability which is different for each crop, varies from year to year and depends on many other factors such as:

•the harvesting method;

•the moisture content;

•the demand of agricultural residues for non-energy purposes (cereal straw, for example, is used for animal feeding, animal bedding, etc.);

•the need for some residues to remain on the soil to maintain the level of nutrients;

\footnotetext{
${ }^{1}$ Milić Čurović (corresponding author: curovic@t-com.me), Katarina Pavićević, Milena Đokić, Dragana Drobnjak, University of Montenegro, Biotechnical Faculty, Podgorica, MONTENEGRO.

Notes: The authors declare that they have no conflicts of interest. Authorship Form signed online.
} 
The main crops producing considerable quantities of field crop residues in Montenegro are potato, maize, wheat, rye and barley. The most important crops on arable land in Montenegro are potato with production of 24.313,1 t in 2014.

The main arboriculture residue resources in Montenegro are vineyards, olives, apples, plums, pears and citrus fruits pruning. Vineyards pruning are the most significant source of biomass to the total crop residues potential. Furthermore, citrus fruits, apples, plums, olives and pears contribute also significantly to the arboriculture residues potential.

The exploitation of livestock residues for energy production through anaerobic digestion process would be feasible only in cases of medium-large scale livestock units. Residues from cattle breading contribute the highest share to the total potential.

Due its specific natural conditions Montenegro has small areas of arable land that are underutilized, which could be used for energy crops.

There are multiple options for biomass utilization for energy purposes of which various forms of burning prevail. Biogas production by way of anaerobic fermentation is the dominant form of use of livestock residue. From the remaining methods, methyl ester production from bio-oils and alcohol production are the most frequent.

The use of biomass for bioenergy creates new business opportunities in agriculture sector. Bioenergy production can significantly contribute to the development of rural areas and encourage creating new supply chains for biomass feedstock. The creation of new non-food markets for biomass could provide alternative income sources for farmers (EC 2012)

Agricultural residues, may act as important source of renewable energy. Studies assessing the availability of this resource offer little insight on the drivers and constraints of the available potential as well as the associated costs and how these may vary across scenarios (Diaoglou et al 2016).

Bilandzija et al. (2016) reported on how much biomass could be obtained by pruning of plantations of respective fruit cultures in Croatia. The energy potential of the pruned fruit biomass in Croatia is calculated at $4.21 \mathrm{PJ}$ (1170GWh).

Potential of residual biomass as source of energy in the Czech Republic is about 121PJ/year which equals to $6.8 \%$ of primary energy sources used in 2012 (Vavrova et al. 2014). In Macedonia (Kanevce et al. 2016) the biomass accounted for $6.6 \%$ of the primary energy consumption in 2012, and $10.4 \%$ in the final energy consumption. The biomass residues potential were calculated on similar way in Albania (Karaj et al. 2009) Turkey (Elicin et al. 2014), Italy (Chinnici et al. 2015) etc. and shows importance of studies for assessment of biomass potential and availability.

\section{MATERIAL AND METHODS}

Potential is calculated per each source type. Livestock energy potential $\left(\mathrm{L}_{\mathrm{ep}}\right)$ is calculated based on formula: 
Where:

$$
\mathrm{L}_{\mathrm{ep}}=\mathrm{N} \cdot \mathrm{F} \cdot \mathrm{Y} \cdot \mathrm{H}
$$

$\mathrm{N}$ - number of animal species

$\mathrm{F}$ - manure generation factor for species [t/head/yr]

$\mathrm{Y}$ - coefficient of biogas yield [ $\mathrm{Nm}^{3} / \mathrm{t}$ manure]

$\mathrm{H}$ - heating value of biogas [GJ/ $\left.\mathrm{Nm}^{3}\right]$

According to Bogunovic et al. (2009) and CRES (2010) the technical potential was regarded equal to $30 \%$ of the theoretical value.

Table 1. Parameters for energy production from livestock residues.

\begin{tabular}{|l|c|c|c|}
\hline & $\begin{array}{c}\text { waste per animal } \\
(\mathrm{t} / \mathrm{yr})^{*}\end{array}$ & $\begin{array}{c}\text { biogas yield } \\
\left(\mathrm{Nm}^{3} / \mathrm{t} \text { of waste }\right)\end{array}$ & $\begin{array}{c}\text { biogas LHV } \\
\left(\mathrm{GJ} / \mathrm{Nm}^{3}\right)\end{array}$ \\
\hline Cattle & 1,62 & 245 & 0,0216 \\
\hline Pigs & 0,30 & 430 & 0,0216 \\
\hline Poultry & 0,021 & 450 & 0,0234 \\
\hline
\end{tabular}

*Source: CRES (2010)

The annual energy for each crop cultivated in Montenegro 2014. (Monstat 2015), is calculated based on the following formula:

$$
\mathrm{C}=\mathrm{R} \cdot \mathrm{P} \cdot \mathrm{H}
$$

$\mathrm{R}$ - ratio of residue over main product [t/t]

$\mathrm{P}$ - annual production of product cultivated $[\mathrm{t}$ ]

$\mathrm{H}$ - heating value of residue [GJ/t]

The availability factor for arable crop residues is $30 \%$ mainly due to technical difficulties in collecting. The availability factor for arboriculture residues is $90 \%$. The factor for olives $50 \%$ was estimated based on our previous experience in Greece (Mardikis et al. 2004).

\section{Livestock}

\section{RESULTS AND DISCUSSION}

In rural areas of Montenegro agriculture is the most important sector, also livestock production is most important branch of agriculture.

Montenegro has specific natural conditions with large areas of natural meadows and pastures (210,618.0 ha in 2014), which are suitable expecialy for extensive livestock production. Livestock sector in Montenegro is composed of small-scale farms in general. More than $58 \%$ of the breeding animals are in small farms with 1-3 cows / heifers (MPRR, 2012).

Animal residues are form of biomass that is being well known for energy generation. For the production of biogas very suitable raw material is manure of domestic animals, especially cattle, pigs and poultry. The amount of animal waste residues depends on type and size of animals, number of animal population, domestic animals or confined feedlots and population animal density 
for one location (Karaj et al, 2009). In Montenegro is a problem in collection and storage of manure. In order to generate sufficient quantities of manure for potential biogas production, it is necessary to implement adequate system of manure collecting from the facilities. Energy can be derived from livestock residues as long as they are collected in lagoons or large tanks and can be considered feasible only in install livestock systems. Long grazing periods makes it impossible to collect the animal waste, which excluding sheep and goats from such practices during grazing period.

Official agricultural policy in Montenegro is oriented in maximizing the share of medium and big farms as well as increasing the number of animals per household in next period (MPRR, 2012). This will lead to the actualization of the problem of disposal of liquid manure. One of the solutions for the use of this residue will be certainly to use it as energy source.

According to official statistics (MONSTAT, 2015) in Montenegro were 93.550 heads cattle, 22.053 pigs, and 595.675 chickens in 2014. During recent years, positive changes have been recorded in the consolidation of holdings and in an increase in the number of heads. In comparison with last few year (2012, 2013), in 2014 was observed increase number of cattle and pig. Because of that was increase the amount of produced manure and in 2014 it was 107.675t in total.

Table 2. Livestock residues theoretical potential in Montenegro (2014)

\begin{tabular}{|l|l|l|l|l|}
\hline & Cattle & Pigs & Chicken & Total \\
\hline Number of animals & 93.550 & 22.053 & 595.675 & 711.278 \\
\hline Residues (t) (dry) & 151.551 & 6.615 & 12.509 & 107.675 \\
\hline $\begin{array}{l}\text { Biogas potential (million } \\
\text { Nm}^{3} \text { ) }\end{array}$ & 37,12 & 2,84 & 5,62 & 45,58 \\
\hline Theoretical Potential (GJ) & 802.007 & 61.448 & 131.721 & 995.176 \\
\hline Technically available & & & & $30 \%$ \\
\hline Technical Potential (GJ) & & & & 298.552 \\
\hline
\end{tabular}

*Source: Monstat 2015.

Presented data in table 2 shows that on the basis residues produced on average per animal and the biogas yield per ton of produced residues, the amount of biogas that could be theoretically produced amounts to 45,58 million $\mathrm{Nm}^{3}$, which is equivalent to $995.176 \mathrm{GJ}$ or $276,437 \mathrm{GWh}$.

Because of the low technical availability technical energy potential of the livestock residues in Montenegro is just 298.552 GJ (82,931 GWh).

\section{Plant production}

Energy potential of field crop residues (32753 GJ) are significantly lower in relation to the production of arboricultural and amounts to only $23 \%$ of the total energy potential of $142283 \mathrm{GJ}-39,56 \mathrm{GWh}$ (Table 3.). 
Table 3. Agricultural plant production structure in Montenegro and residue quantity in 2014.

\begin{tabular}{|c|c|c|c|c|c|c|}
\hline \multirow[t]{3}{*}{ Crop } & \multirow[t]{3}{*}{ Production } & \multirow[t]{3}{*}{ Residues } & \multirow[t]{3}{*}{$\begin{array}{c}\text { Degree of } \\
\text { Availability }\end{array}$} & \multicolumn{3}{|c|}{$\begin{array}{l}\text { Residues available for } \\
\text { energy exploitation }\end{array}$} \\
\hline & & & & \multirow{2}{*}{$\begin{array}{c}\text { Quantity } \\
\text { (t) }\end{array}$} & \multicolumn{2}{|c|}{ Energy potential } \\
\hline & & & & & GJ & GWh \\
\hline Total & 36621 & 15767 & & 9490 & 142283 & 39,56 \\
\hline Fields & 7138 & 7293 & & 2188 & 32753 & 9,11 \\
\hline Wheat & 2159 & 2159 & 30 & 648 & 9331 & 2.60 \\
\hline Maize & 3305 & 3636 & 30 & 1091 & 16911 & 4,70 \\
\hline Barley & 1147 & 918 & 30 & 275 & 3988 & 1,11 \\
\hline Ray & 527 & 580 & 30 & 174 & 2523 & 0,70 \\
\hline \begin{tabular}{|l|} 
Arboricultural \\
\end{tabular} & 29483 & 8474 & & 7302 & 109530 & 30,45 \\
\hline Plums & 5743 & 1436 & 90 & 1292 & 19380 & 5,40 \\
\hline Apple & 4900 & 1715 & 90 & 1544 & 23160 & 6,43 \\
\hline Pears & 915 & 229 & 90 & 206 & 3090 & 0,86 \\
\hline Olives & 796 & 812 & 50 & 406 & 6090 & 1,70 \\
\hline \begin{tabular}{|l|} 
Vineyard \\
\end{tabular} & 17129 & 4282 & 90 & 3854 & 57810 & 16,06 \\
\hline
\end{tabular}

"Source: Monstat 2015.

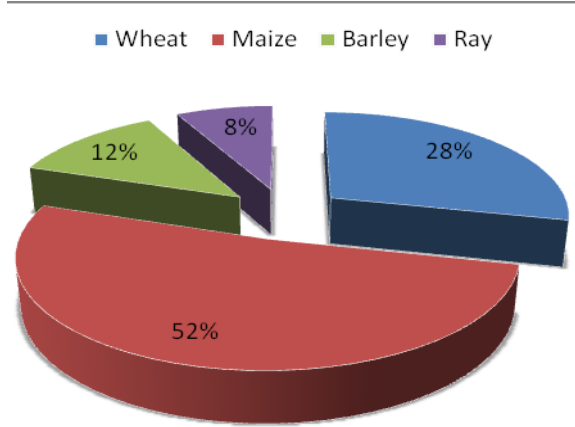

Fig.1. Structure of field crop production

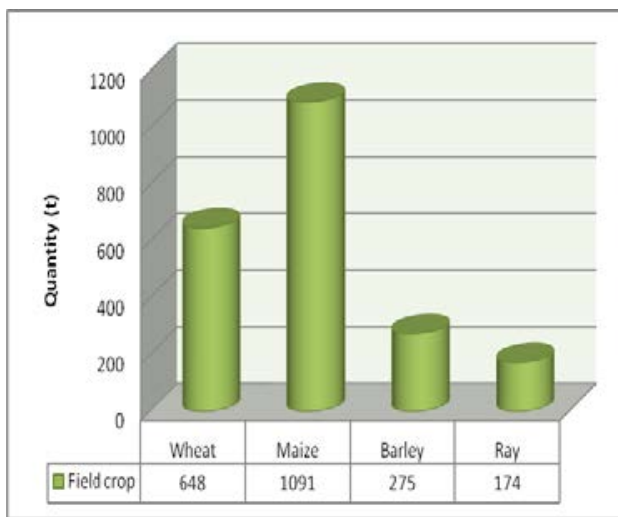

Fig.3. Field crop residue available for energy purposes (in tones)

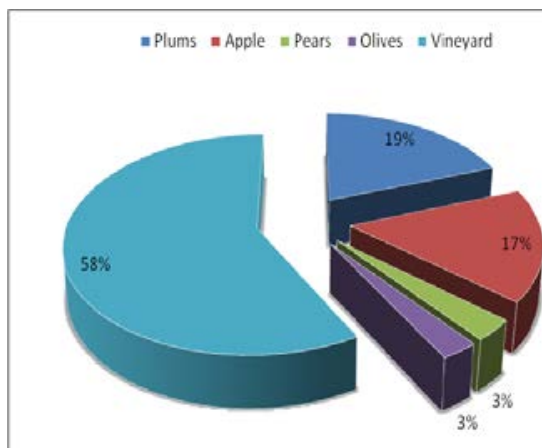

Fig.2. Structure of arboriculture production

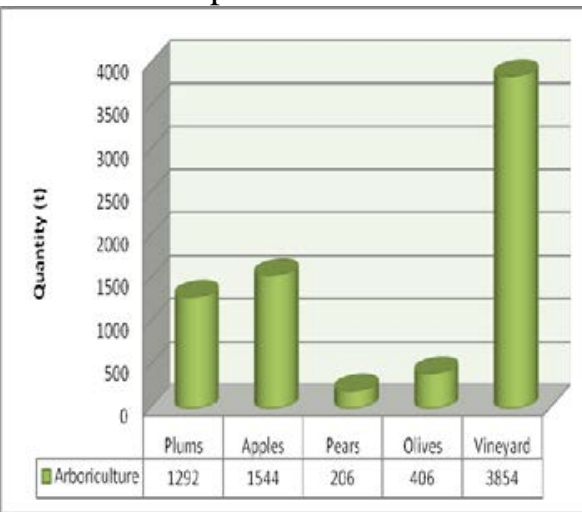

Fig.4. Arboriculture residue available for energy purposes (in tones) 


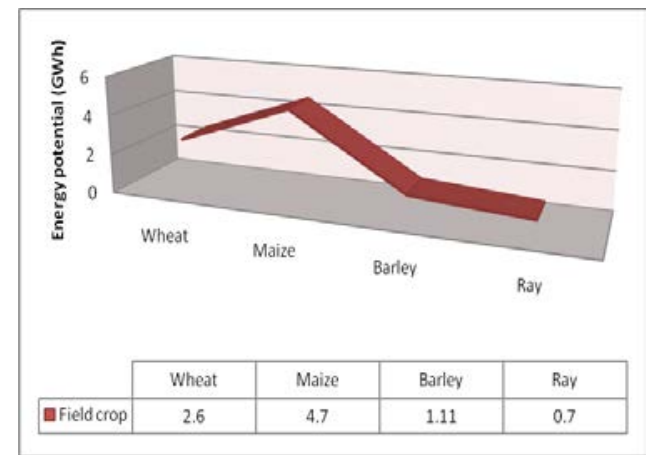

Fig.5. Field crop residue energy potential (GWh)

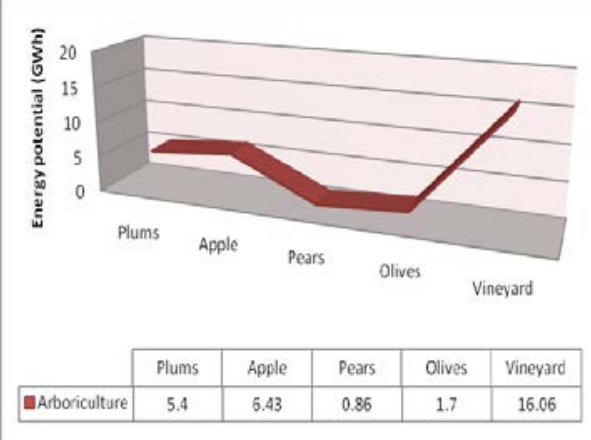

Fig.6. Arboriculture residue energy potential (GWh)

Pruning the orchards are regular agricultural practices. Thermal energy use of biomass residues as pruning is not enough apply in Montenegro because of outdated technology, extensive production and lack of organized collecting, preparing and using of plants remains.

The majority of fruit crops are grown on a small scale without the use of agro-techniques (plowing, fertilizing, cutting, protection from pests and frost, irrigation). In 2014 arboriculture residues amounted 29483 t with energy potential of $109530 \mathrm{GJ}$ (30,45 GWh).

Presented amounts show that fruit growing sector is on very low level. For example in The Republic of Serbia has approximately 600,000 t wood biomass from fruit and grape plantations (Zivkovic et al. 2013).

Of the total arboricultural production, production of olives is $19 \%$, and $58 \%$ of the vineyards, and they make one of the most important factors for obtaining biomass. Unfortunately, the use of olive residues is only $50 \%$. The remains of the olives are very important, especially residues from olive oil, which amounts to $80 \%$, because they contain vegetable water, pulp and stones from the olives, and the hard part has a high heating value.

Vineyards pruning are the most significant source of biomass contributing almost by half $(40,6 \%)$ to the agricultural plant production residues potential.

The overall potential of timber biomass residue from vineyards and orchards is by research of prof. Glavonjic (2012) 2.482 tons per year. The overall potential of agricultural biomass residue is 8.154 tons per year. According The Action Plan for the wood biomass, the total area under vine in Montenegro in 2011 amounted to about 4,5 thousand ha with 18,44 million grapevines stems. Based on the known parameters of the amounts of biomass per hectare in the process of pruning vines, which can be put into operation production of fuel annually from the economic point (profitability) (Cotan and Cavalaglio 2008) in viticulture in Montenegro incurred 12.543 tons of wood waste whose energy value is $37.629 \mathrm{MWh}$.

Agricultural policy in Montenegro tries to revive fruit production by set of subsidies. Thus, last year is recorded 85ha of new fruit plantations. A noticeable 
increase is also in the field of olive growing. In process of creating policy in the sector of plant production should bear in mind the limitations due to climate changes (Curovic and Spalevic, 2010)

However, despite progress in these segments of crop production, the greatest potential for the use of biomass as fuel is seen in viticulture. Montenegro is interesting for the cultivation of vineyards. It is expected increase of land surface under vines in the future. According to presented data from the sector of plant production only Viticulture has the potential of the commercial exploitation of biomass residues for energy purposes. Production of briquettes made of biomass residue from vineyards could be realistic option.

\section{CONCLUSIONS}

The theoretical energy content of biomass of Agricultural residues in Montenegro is $440.835 \mathrm{GJ}(122,49 \mathrm{GWh})$ per year.

Currently there is no usage of agricultural land for energy crops or organized usage of agricultural residues for energy production in Montenegro. It is realistic to expect the first examples of the use of residues in the coming period, especially in the sectors of livestock and viticulture. This paper shows that there is potential for utilization of biomass residue as an energy source in these sectors.

\section{ACKNOWLEDGEMENTS}

This study was supported by TEMPUS Project: Renewable energy Studies in Western Balkan countries - RESI.

\section{REFERENCES}

Bilandzija N, Voca N, Kricka T, Matin A, Jurisic V. (2012): Energy potential of fruit tree pruned biomass in Croatia. Spanish J Agric Res;10(2):292-8.

Bogunovic, A., Bogdanov, N. (2009): Analysis of renewable energy and its impact on rural development in Serbia. Agripolicy, Enlargement network for agripolicy analysis.

Chinnici, G., D Amico, M., Rizzo M., Pecorino, B. (2015): Analysis of Biomass Availability for Energy Use in Sicily, Renew Sustain Energy Rev, 52, Dec., pp. 1025-1030

Cotana F., Cavalaglio G.(2008): Polygeneration from vineyards pruning residues in an Umbrian wine company, Peach, Vol.67, issue 2, p.9

CRES (2010): Biomass in Montenegro; p. 1-47

Curovic, M. and Spalevic, V. (2010): Climate changes impacts on forests in Montenegro mitigation and adaptation; International Conference - Forest ecosystems and Climate changes; March 9-10th Belgrade, Serbia, p.283-287, IUFRO; EFI; Institute of forestry, Beograd.

Daioglou V., Stehfest E., Wicke B., Faaij A. And Van Vuuren D.P. (2016): Projections of the availability and cost of residues from agriculture and forestry, GCB Bioenergy (2016) 8, 456-470, doi: 10.1111/gcbb.12285

EC. (2012): Bioeconomy strategy, innovating for sustainable growth: a bioeconomy for Europe. Brussels 
Eliçin K., Gezici M., Tutkun M., Şireli D., Öztürk F., Koser Eliçin M., Gürha R. (2014): Potential of biogas from animal wastes of Turkey and determination of suitable reactor size. Agriculture \& Forestry, Vol. 60 Issue 4: 189-197, Podgorica.

Glavonjić B. (2010): Possibilities, Challenges and Current Progress in Wood Biomass Market Development in Montenegro, FODEMO

Government of Montenegro Ministry of Agriculture and Rural Development (2015): Strategy for the development of agriculture and rural areas 2015-2020

Kamila Vávrová, JaroslavKnápek, JanWeger (2014): Modeling of biomass potential from agricultural land for energy utilization using high resolution spatial data with regard to food security scenarios; Renewable and Sustainable Energy Reviews 35, p.436-444

Kanevce G., Dedinec A., Dedinec Aleksandra (2016): Optimal usage of biomass for energy purposes toward sustainable development- A Case of Macedonia; THERMAL SCIENCE, Vol. 20, Suppl. 1, pp. S77-S91

Karaj S., Rehl T., Leis H.and Muller J. (2009): Analysis of biomass residues potential for electrical energy generation in Albania, Renewable and Sustainable Energy Reviews, vol. 14

Mardikis, M., Nikolaou, A., Djouras, N. and Panoutsou, C. (2004): Agricultural biomass in Greece. Biomass and Agriculture: Sustainability, Markets and Policies. p. 363376. OECD publications, ISBN 92-64-10-555-7

MONSTAT (2009): Statistical yearbook 2009; Montenegro statistical office

MONSTAT (2012): Statistical yearbook 2012; Montenegro statistical office

MONSTAT (2013): Statistical yearbook 2013; Montenegro statistical office

MONSTAT (2015): Statistical yearbook 2015; Montenegro statistical office

MPRR (2012): Izvještaj o analitičkom pregledu usklađenosti zakonodavstva Crne Gore, Poglavlje 11- Poljoprivreda i ruralni razvoj, Minstarstvo poljoprivrede i ruralnog razvoja

Živković M., Urošević M., Oljača S., Oljača M., Gligorević K., Zlatanović I., Koprivica R. (2013): Aspects of using potential energy products of biomass after pruning fruit and grape plantations in the Republic of Serbia. Agriculture \& Forestry, Vol. 59. Issue 1: 167-182, Podgorica 